\title{
INITIAL ASSESSMENT OF THE WEATHER RESEARCH AND FORECASTING MODEL FOR FORECASTING BIOCLIMATIC CONDITIONS DURING BREEZE CIRCULATION - CASE STUDY OF THE SŁOWIŃSKI NATIONAL PARK
}

\author{
BARTOsz CZERneCKI \\ Institute of Physical Geography and Environmental Planning, Adam Mickiewicz University in Poznań, Poland \\ Center for Poland's Climate Monitoring, Institute of Meteorology and Water Management - National Research \\ Institute, Warsaw, Poland
}

MAReK PóŁrolniczaK

Institute of Physical Geography and Environmental Planning, Adam Mickiewicz University in Poznań, Poland

Manuscript received: October 18, 2012

Revised version: July 5, 2013

\begin{abstract}
CZERneCKi B., PóŁrolnicZAK M., Initial assessment of the Weather Research and Forecasting model for forecasting bioclimatic conditions during breeze circulation - case study of the Słowiński National Park. Quaestiones Geographicae 32(3), Bogucki Wydawnictwo Naukowe, Poznań, pp. 5-14. 3 tables, 7 figs. DOI 10.2478/quageo-2013-0021, ISSN 0137-477X.

AвSTRACт. Land-sea interaction at the Polish Baltic Coast impacts the specific local climate conditions. Thermally driven circulation, observed mainly in the summer season, causes the advection of the cool sea air over land and influences the local atmospheric environment, including bioclimatic conditions. The aim of this paper is to present the evaluation of the WRF model for forecasting sensitive bioclimatic conditions on a selected day with sea breeze in the vicinity of the Łeba Sandbar (the Słowiński National Park). The results obtained from a numerical weather prediction model were post-processed to calculate the daily variability of two biothermal indices: the Effective Temperature (ET) and the Dry Cooling Power $(\mathrm{H})$. To evaluate the thermal comfort of a person wearing typical clothes, the Michajlow's, Petrovič and Kacvińsky's scales were adopted. A detailed analysis performed for 31st July 2010 shows in most cases a satisfactory level of agreement between the simulated data and the in-situ measurements for nested domains with horizontal grid resolution less than $2 \mathrm{~km}$. However, the simulation results tend to underestimate the thermal comfort, especially in the middle part of the Łeba Sandbar due to terrain data misrepresentations, which results in the overestimation of wind speed.
\end{abstract}

KEY WORDS: breeze circulation, sea breeze index, WRF, the Słowiński National Park, bioclimatic conditions

Address of the corresponding author: Bartosz Czernecki, Institute of Physical Geography and Environmental Planning, Adam Mickiewicz University in Poznań, Dzięgielowa 27, 61-680 Poznań, Poland; e-mail: nwp@amu.edu.pl

\section{Introduction}

The climate conditions of the Słowiński National Park are to a large extent affected by the land-sea interactions, which modify the air flow on a synoptic scale. This situation is particularly well seen during the summer months, when breeze circulation occurs with the typical off- 
shore and onshore winds, which bring cool maritime air over warmer land.

There are many papers concerning the effects of breeze circulation on human thermal comfort. However most of them focus on regions, where breeze circulation is a common phenomenon (e.g. Papanastasiou et al. 2010, Simpson 1994). According to Michalczewski's (1967) research, breeze circulation in the Polish Baltic Coast (Kondracki 2002) is observed most often in the Gulf of Gdansk, mainly due to the shadow effect of the Kashubia region (Borzyszkowski et al. 1999) against prevailing western winds. The average number of days with breeze at the Polish coast is estimated at 25 days per year, and over $50 \%$ of such days occur in the summer season (Michalczewski 1967), thus significantly modifying the perceived thermal conditions. In most cases, an effect of the onshore wind is positive, mainly due to the specific cooling and refreshing properties of the wind, which have a stimulating effect on human body and prevent air stagnation in coastal regions (Błażejczyk 1980). The time shift between land and sea breeze is a dominant factor on fluctuations in air temperature and air humidity of the coastline area (Świątek 2004, Tijm et al. 1999), what in connection with sudden change of wind direction, especially on days with small cloudiness, may result in a rapid change of the temperature and relative humidity values, which in turn may cause serious disturbances in the heat balance of the human body (Błażejczyk 1980).

Therefore forecasting of local, thermally driven circulation may play a crucial role on many fields of human activity in the coastal regions, like in the case of Łeba surroundings, where fluctuations of a bioclimatic conditions are in strong interest of tourists, tour organizers, travel agencies, tourism planners, and stakeholders (Matzarakis 2006). In order to get an appropriate forecast, the modern high-resolution numerical weather prediction models has to be evaluated to get the answer whether they are capable to recognize local factors like sea breeze. What's more, currently tested mesoscale models used in a operational weather services are getting to work in horizontal resolution much below $5 \mathrm{~km}$ grid, what may suggest better realism of local phenomenon representation.
Taking into account the foregoing, one of the main aims of this paper is to describe the impact of breeze circulation on selected bioclimatic indices (perceived thermal conditions) over relatively short time periods. However, the major objective of the presented research is to evaluate the possibilities of accurate forecasting of breeze circulation and its specific aspects in the researched area, as they may have important implications not only for the bioclimatic indices, but also for other areas of human activity, where numerical weather prediction models are commonly used.

\section{Materials and methods}

The results presented further herein were obtained on the basis of in-situ measurements at two sites. Both measurement locations represent conditions typical of the most often visited tourist places of eastern parts of the Słowiński National Park.

The field station of the Climatology Department of Adam Mickiewicz University is located $10 \mathrm{~km}$ west of Łeba and approximately 30 meters from the Baltic Sea coast. The station is situated between the frontal dunes strip and a coniferous forest, on a flat, sandy area randomly covered with low-growing grass, forming a plant community known as Helichryso-Jasionetum (Bednorz, Kolendowicz 2010, Półrolniczak 2011). Measurements were carried out using the Vaisala MAWS301 automatic weather station, with the anemometer located at the height of $3.75 \mathrm{~m}$.

Biometeorological conditions of the middle part of the Łeba Sandbar were compared with the conditions prevailing at the station in Łeba-Rąb$\mathrm{ka}$, which is run by the Institute of Meteorology and Water Management - National Research Institute (IMGW - PIB) and complies with the WMO requirements. This station is located nearby the Łebsko Lake, approximately $1.5 \mathrm{~km}$ from the Baltic Sea. It is worthy of note that the station is not directly affected by the Baltic Sea due to the several hundred meter wide forest strip located between the sea and the lake area (Fig. 1).

In order to distinguish whether it is possible to forecast breeze occurrence with characteristic for this phenomenon daily change of bioclimatic conditions, a 24 hour forecast was produced using 


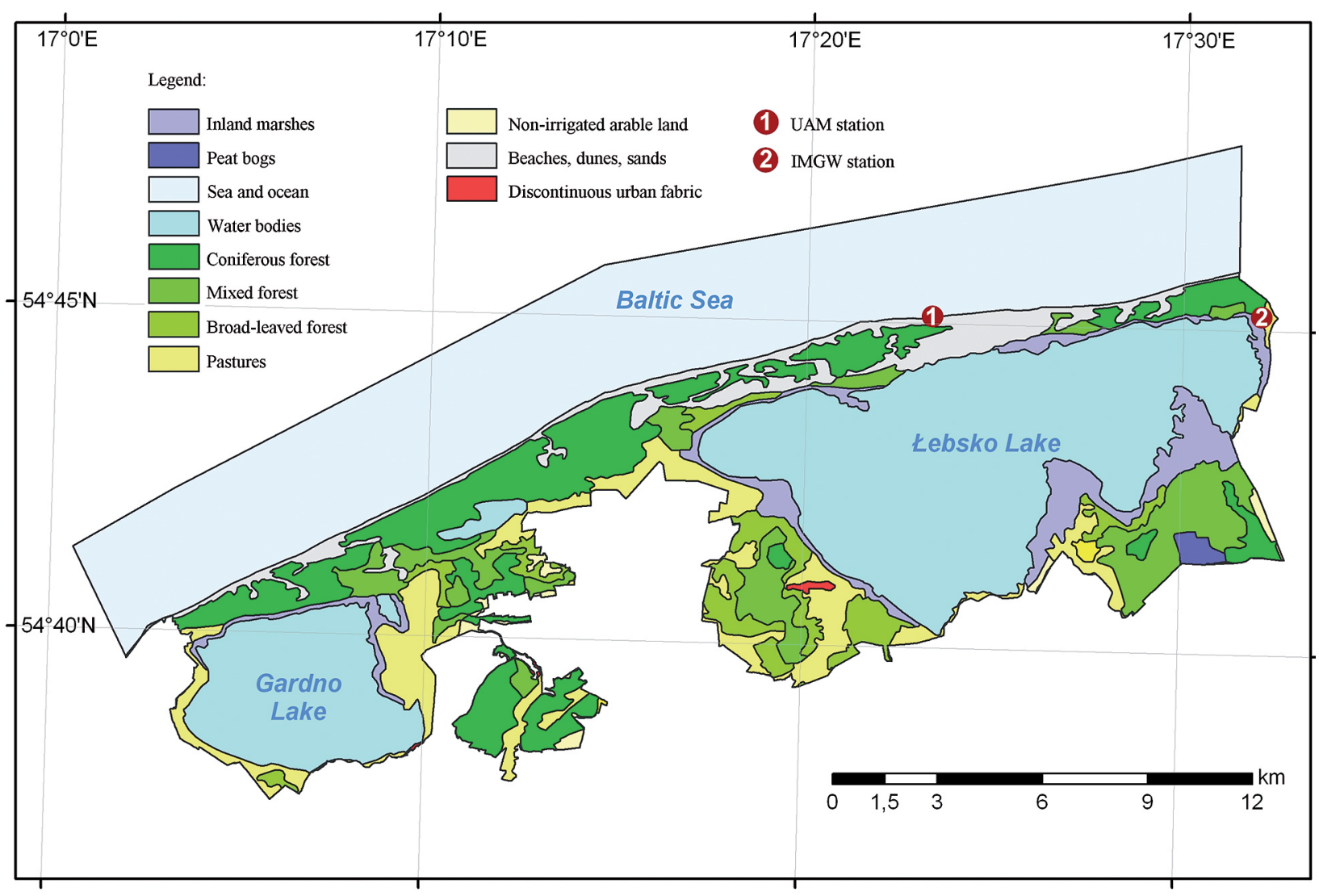

Fig. 1. Location of meteorological stations used in this study. Land use categories inside the Słowiński National Park according to CORINE 2006 (JRC-EEA 2005)

a mesoscale numerical weather prediction model WRF 3.1 (Weather Reaseach and Forecasting Model). The boundary conditions were extracted at 00 and 12 UTC, with horizontal resolution of $0.5^{\circ}$ based on the global simulation of the GFS model (Global Forecast System). Data assimilation of the boundary conditions was done every
3 hours as delivered by the large-scale model. Due to the local character of breeze circulation, which cannot be recognized by global models, and in order to avoid a sharp resolution change, the 5-way nesting technique was applied (Fig. 2, Table 1). The horizontal grid spacing obtained for the smallest of the created domains was only 0.46
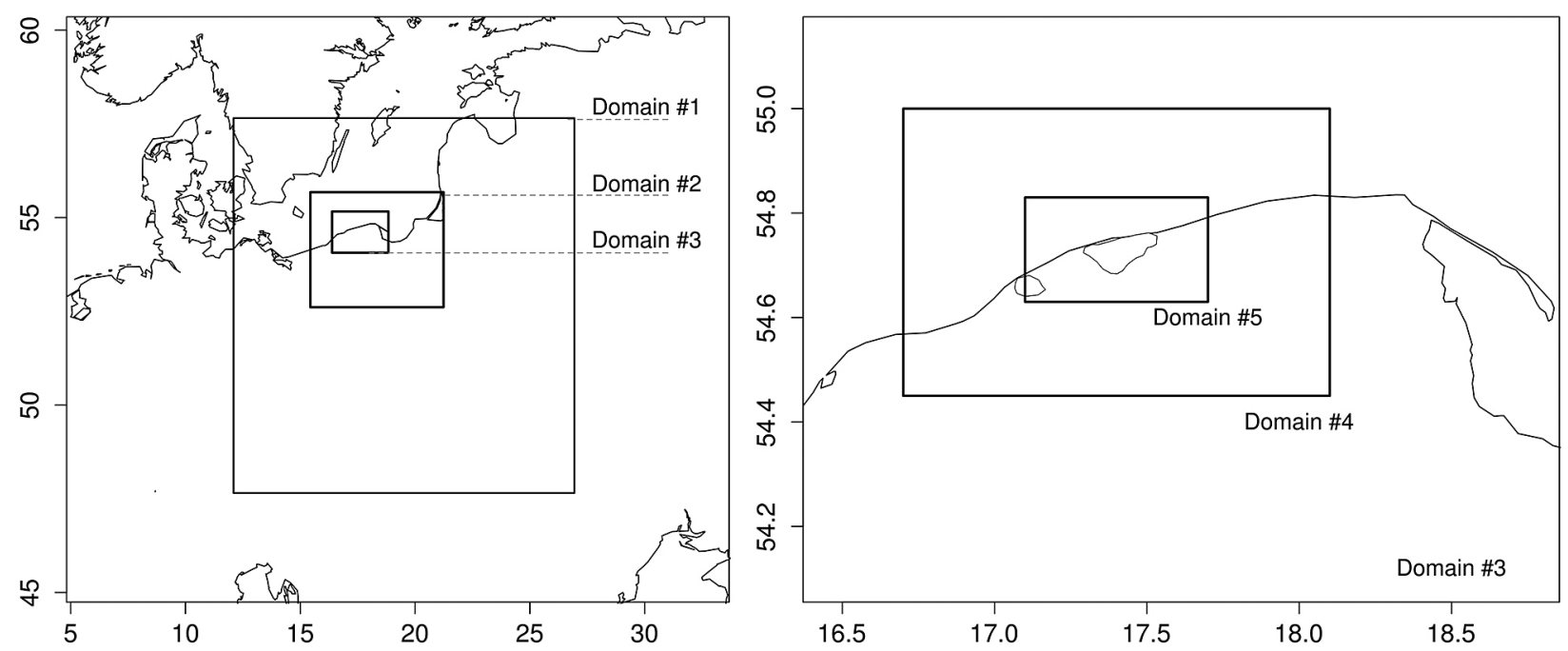

Fig. 2. Nesting of domains 1-5 used in simulations run by the WRF model 
BARTOSZ CZERNECKI, MAREK PÓŁROLNICZAK

Table 1. Selected details of domains used in the simulation made by the WRF model

\begin{tabular}{|l|c|c|c|c|c|}
\hline & Domain 1 & Domain 2 & Domain 3 & Domain 4 & Domain 5 \\
\hline Time step & $240 \mathrm{~s}$ & $60 \mathrm{~s}$ & $20 \mathrm{~s}$ & $6.66 \mathrm{~s}$ & $2.22 \mathrm{~s}$ \\
\hline $\begin{array}{l}\mathrm{d} x, \mathrm{dy} \\
\text { (total number of cells) }\end{array}$ & $\begin{array}{c}24 \times 24 \\
(576)\end{array}$ & $\begin{array}{c}33 \times 29 \\
(957)\end{array}$ & $\begin{array}{c}40 \times 31 \\
(1240)\end{array}$ & $\begin{array}{c}64 \times 46 \\
(2944)\end{array}$ & $\begin{array}{c}79 \times 49 \\
(3871)\end{array}$ \\
\hline Number of vertical layers (up to 50hPa) & \multicolumn{5}{|c|}{45} \\
\hline Horizontal grid resolution & $50.00 \mathrm{~km}$ & $12.50 \mathrm{~km}$ & $4.17 \mathrm{~km}$ & $1.39 \mathrm{~km}$ & $0.46 \mathrm{~km}$ \\
\hline
\end{tabular}

Table 2. A list of important physical settings of the WRF 3.1 model used in this study

\begin{tabular}{|l|l|}
\hline \multicolumn{1}{|c|}{ Model characteristics } & \multicolumn{1}{c|}{ Type } \\
\hline Model core & Advanced Research WRF (ARW), nonhydrostatic \\
\hline Initial and lateral boundary & $0.5^{\circ}$ - resolution GFS \\
\hline $\begin{array}{l}\text { Cumulus parametrization } \\
\text { scheme }\end{array}$ & $\begin{array}{l}\text { Kain-Fritsch scheme for 1st domain - a deep and shallow sub-grid scheme using } \\
\text { a mass flux approach with downdrafts and CAPE removal time scale. (Kain 2004). } \\
\text { Domain 2-5 with no cumulus parametrization }\end{array}$ \\
\hline Microphysics schemes & $\begin{array}{l}\text { Lin } \text { et al. scheme: A sophisticated 5-class scheme that has ice, suitable for real-data } \\
\text { high-resolution simulations (Lin } \text { et al. 1983, Chen and Sun 2002) }\end{array}$ \\
\hline $\begin{array}{l}\text { Planetary Boundary Layer } \\
\text { (PBL) scheme }\end{array}$ & $\begin{array}{l}\text { Yonsei University scheme. Depth of PBL determined from thermal profile. (Skama- } \\
\text { rock et al. 2005) }\end{array}$ \\
\hline Land surface physics scheme & $\begin{array}{l}\text { Noah Land Surface Model: Unified NCEP/NCAR/ AFWA scheme with soil tem- } \\
\text { perature and moisture in four layers. Vegetation effects included. Diagnoses skin } \\
\text { temperature and uses emissivity. Provided heat and moisture fluxes to the PBL } \\
\text { (Chen, Dudhia 2001) }\end{array}$ \\
\hline Urban canopy model & Off \\
\hline $\begin{array}{l}\text { Long and short wave radiation } \\
\text { scheme }\end{array}$ & Rapid Radiative Transfer Model (RRTM) (Mlawer et al. 1997). \\
\hline $\begin{array}{l}\text { Sea Surface Temperature } \\
\text { support }\end{array}$ & Yes \\
\hline Orography & U.S. Geological Survey (USGS) Digital Elevation Model (30s) \\
\hline
\end{tabular}

$\mathrm{km}$, but even though, not all terrain details, such as the coastline or land cover, deriving from the default USGS 30-arc-second data, were not properly represented. It should also be remembered that there are some limitations in prescribing the initial conditions of the sea surface temperature (SST), which are often in mesoscale models assimilated by climatology means. More details of the important settings used in the simulation are presented in Table 2.

The authors are aware that the evaluation of the model requires specific and long-term testing.

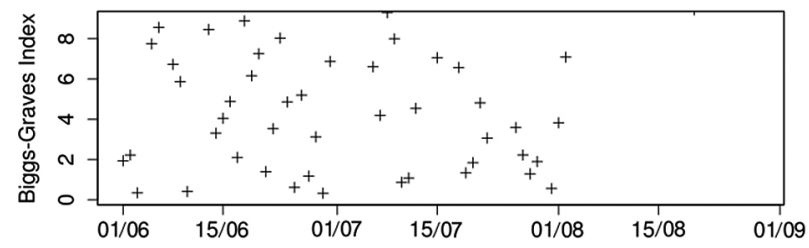

Fig. 3. The Biggs-Graves Index (1962) values in the Łeba Sandbar during summer season of 2010
However, this paper rather focuses on a general evaluation whether the selected high-resolution mesoscale model and selected model setup may be used to predict breeze circulation. In case of a positive answer to that question, it will be important to identify the meteorological elements, which affect sensitive temperature, including those which can be forecast well and those which are difficult to forecast.

In order to determine a day with sea breeze circulation, the Biggs-Graves index (1962) was calculated for the entire summer season (Fig. 3) using the data obtained from the field station of Adam Mickiewicz University and Reynold's sea surface temperature (SST) re-analysis ${ }^{1}$ (Reynolds et al. 2007). This dimensionless index, also called Eckert index, considers difference of SST

www.ncdc.noaa.gov/oa/climate/research/sst/griddata.php (accessed 31 May 2012). 
and land temperature on the background of geostrophic wind, as shown on eq. 1.

$$
\mathrm{e}=\frac{\mathrm{u}^{2}}{\mathrm{C}_{\mathrm{p}} \cdot \Delta \mathrm{T}}
$$

where:

$\mathrm{C}_{\mathrm{p}}$ - heat capacity of air at constant pressure $\left[\mathrm{JK}^{-1} \mathrm{~kg}^{-1}\right]$

$\mathrm{u}$ - geostrophic wind speed $\left[\mathrm{m} \mathrm{s}^{-1}\right]$,

$\Delta \mathrm{T}$ - temperature difference between land and SST [K].

According to the research of Biggs and Graves' concerning the Lake Erie (1962), breeze circulation mainly occurs when the Eckert index is between 0 and 3 , and the probability of a day with breeze increases when the value is closer to 0 . One such event was diagnosed on 31st July 2010, when the Eckert index was only 0.4. Additionally, the choice of that date for further analysis was justified by a good level of agreement with the synoptic situation over Central Europe by the GFS model, with no active synoptic fronts or widespread cloud zones.

In order to determine the perceived thermal conditions, two biometeorological indicators were applied, i.e. the Effective Temperature (ET), which is a quasi temperature measure, and the Dry Cooling Power $(\mathrm{H})$, which is a physical in-

Table 3. Applied biometeorological indices and chosen scales range

\begin{tabular}{|c|c|c|}
\hline Index & Class range & Effect on human body \\
\hline \multirow{7}{*}{$\begin{array}{l}\text { ET-index } \\
\text { (according } \\
\text { to Micha- } \\
\text { jlow's } \\
\text { thermal } \\
\text { sensation } \\
\text { scale) }\end{array}$} & $<1.0$ & very cold \\
\hline & $1.0-8.9$ & cold \\
\hline & $9.0-16.9$ & $\mathrm{cool}$ \\
\hline & $17.0-20.9$ & fresh \\
\hline & $21.0-22.9$ & comfortable \\
\hline & $23.0-26.9$ & warm \\
\hline & $\geq 27.0$ & hot \\
\hline \multirow{8}{*}{$\begin{array}{l}\text { H-index } \\
\text { (according } \\
\text { to Petro- } \\
\text { vič and } \\
\text { Kacvinsky's } \\
\text { thermal } \\
\text { sensation } \\
\text { scale) }\end{array}$} & $\leq 210.0$ & very hot \\
\hline & $210.1-420.0$ & hot \\
\hline & $420.1-630.0$ & neutral \\
\hline & $630.1-840.0$ & slightly cool \\
\hline & $840.1-1260.0$ & cool \\
\hline & $1260.1-1680.0$ & cold \\
\hline & $1680.1-2100.0$ & very cold \\
\hline & $>2100.0$ & $\begin{array}{l}\text { extremely cold and } \\
\text { windy }\end{array}$ \\
\hline
\end{tabular}

dicator of heat balance between the human body and its environment. The effective temperature (ET) is usually identified as an indicator reflecting the total effect of temperature, relative humidity and wind speed on a normally dressed person or on a person stripped to the waist, but staying in the shade (to not account for solar radiation). It is calculated using Missenard formulas (Kozłowska-Szczęsna et al. 1997) (eq. 2, 3):

$\mathrm{ET}=\mathrm{t}-0.4(\mathrm{t}-10)(1-0.01 \mathrm{f})$, when $\mathrm{v} \leq 0.2 \mathrm{~ms}^{-1}$

$$
\begin{aligned}
\mathrm{ET} & =37-\frac{(37-\mathrm{t})}{\left(0.68-0.0014 \mathrm{f}+\left[\frac{1}{1.76+1.4 \mathrm{~V}^{0.75}}\right]\right)} \\
& -0.29 \mathrm{t}(1-0.01 \mathrm{f}), \text { when } \mathrm{v}>0.2 \mathrm{~ms}^{-1}
\end{aligned}
$$

where:

$\mathrm{t}$-air temperature $\left[{ }^{\circ} \mathrm{C}\right]$,

$\mathrm{f}$ - relative humidity [\%],

$\mathrm{v}$ - wind speed [ $\left.\mathrm{m} \mathrm{s}^{-1}\right]$.

The assessment of the thermal conditions was performed by Michajlow's thermal sensation scale, which takes into consideration a normally dressed man, performing light work (thermal insulation $1 \mathrm{clo}$, which reflects thermal resistance of $0.155 \mathrm{Km} / \mathrm{W}^{2}$ ). The ranges of the ET index presented in Table 3 are most favorable for cool and fresh classes (Kozłowska-Szczęsna et al. 1997).

The Dry Cooling Power $(\mathrm{H})\left(\mathrm{W} / \mathrm{m}^{2}\right)$, also called biological chilling, describes the thermal sensation of a standing person, dressed adequately for the weather. This index determines the heat loss of the human body due to the interactions between air temperature and wind speed. Calculation of the H-index was done using the Hill formulas (Kozłowska-Szczęsna et al. 1997):

$$
\begin{aligned}
& \mathrm{H}=(36.5-\mathrm{t})\left(0.2+0.4\left(\mathrm{v}^{0.5}\right)\right) 41.868 \\
& \text { when } \mathrm{v} \leq 1.0 \mathrm{~ms}^{-1} \\
& \mathrm{H}=(36.5-\mathrm{t})\left(0.13+0.47\left(\mathrm{v}^{0.5}\right)\right) 41.868 \\
& \text { when } \mathrm{v}>1.0 \mathrm{~ms}^{-1}
\end{aligned}
$$

where:

$\mathrm{t}$ - air temperature $\left[{ }^{\circ} \mathrm{C}\right]$,

$\mathrm{v}$ - wind speed $\left[\mathrm{m} \mathrm{s}^{-1}\right]$. 


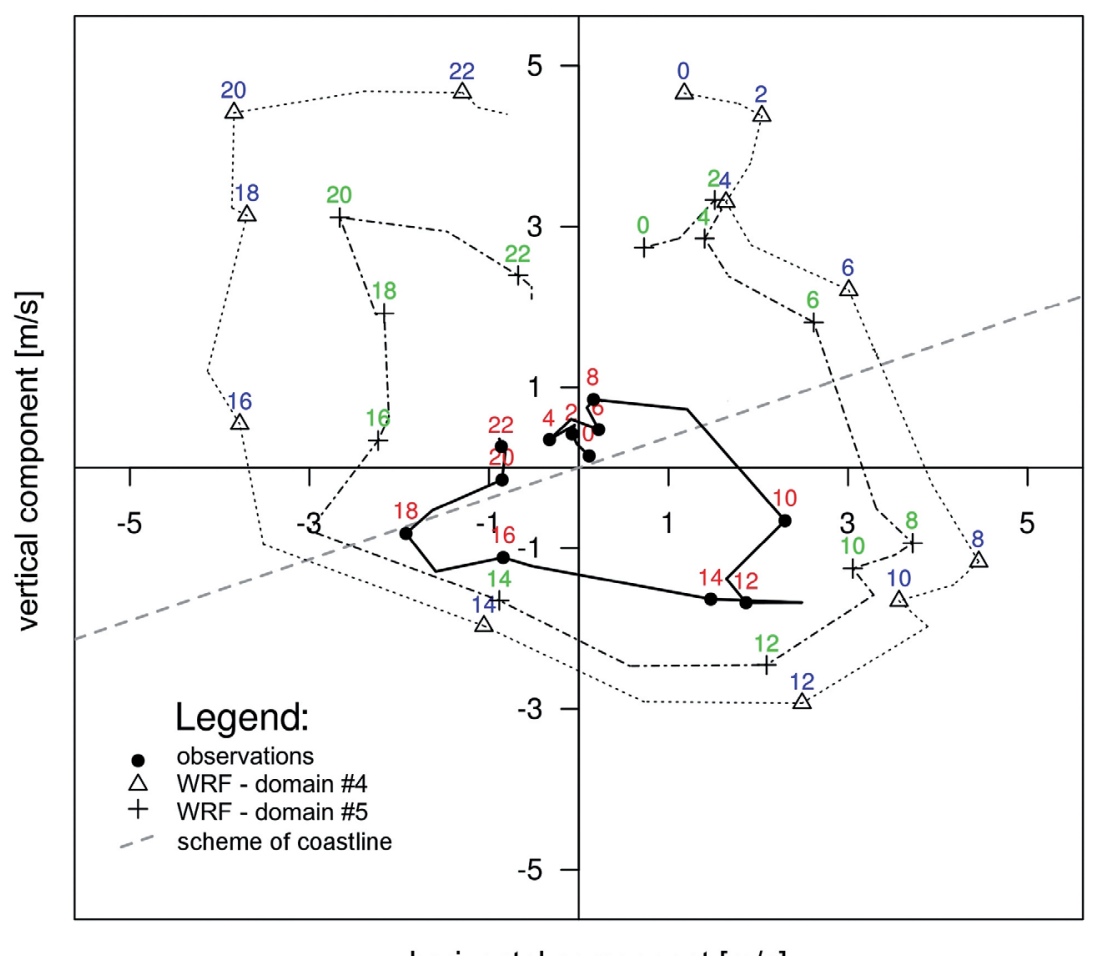

horizontal component [m/s]

Fig. 4a. Wind hodographs at the Łeba Sandbar on 31st July 2010 for observed and modeled data. The numbers represent hours according to local time (UTC+2)

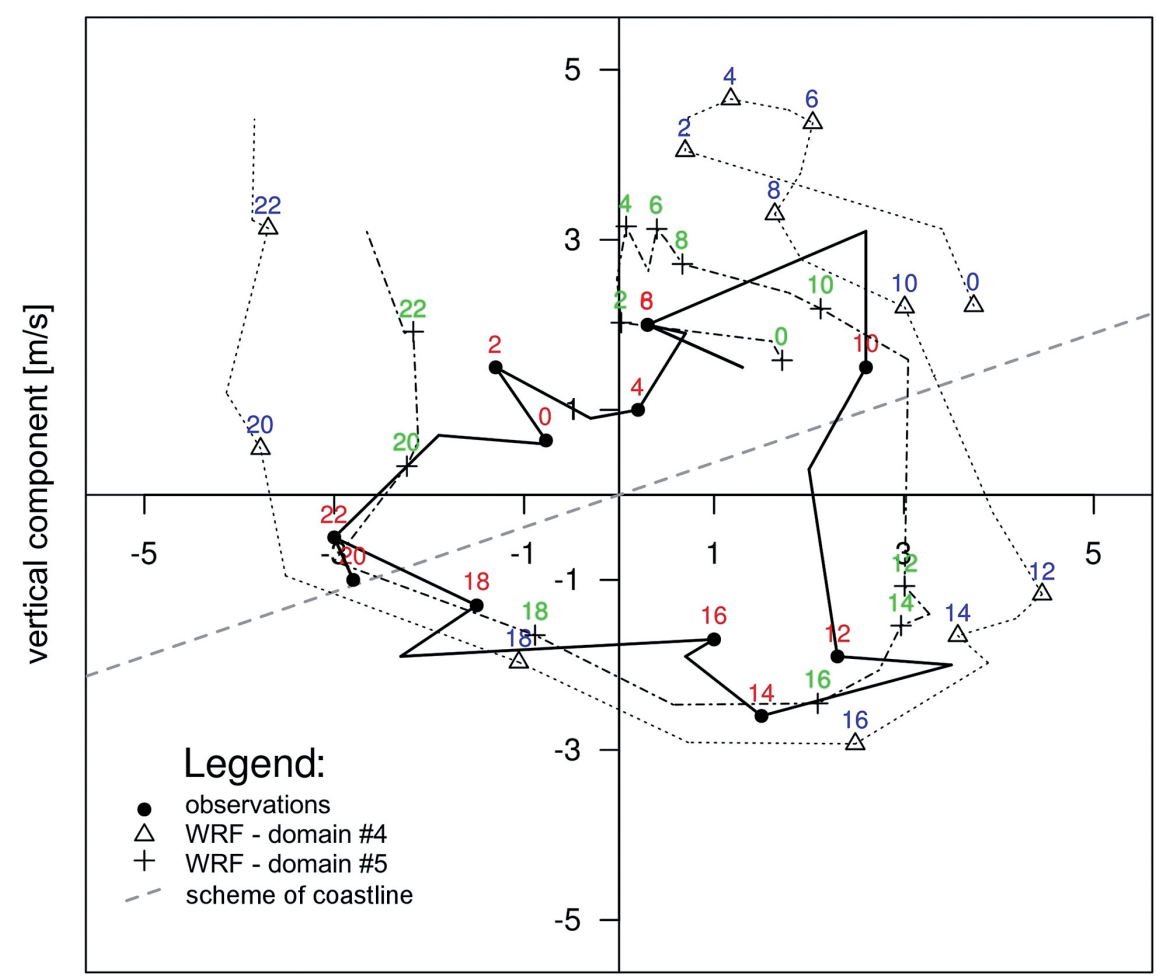

Fig. 4b. Wind hodographs at the Łeba-Rąbka on 31st July 2010 for observed and modeled data. The numbers represent hours according to local time (UTC+2) 
The Keba Sandbar

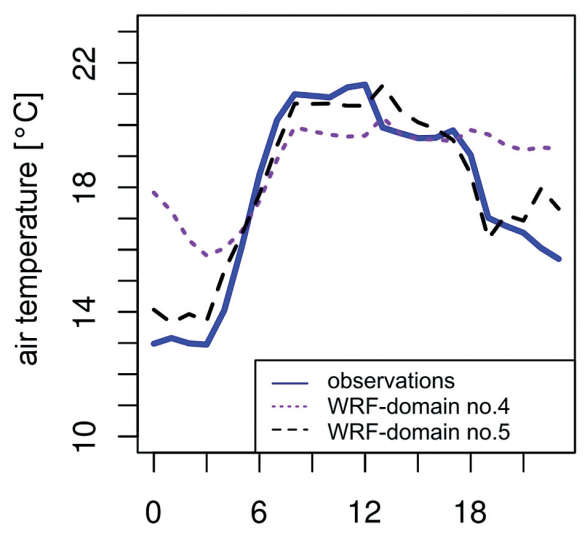

Łeba - Rąbka

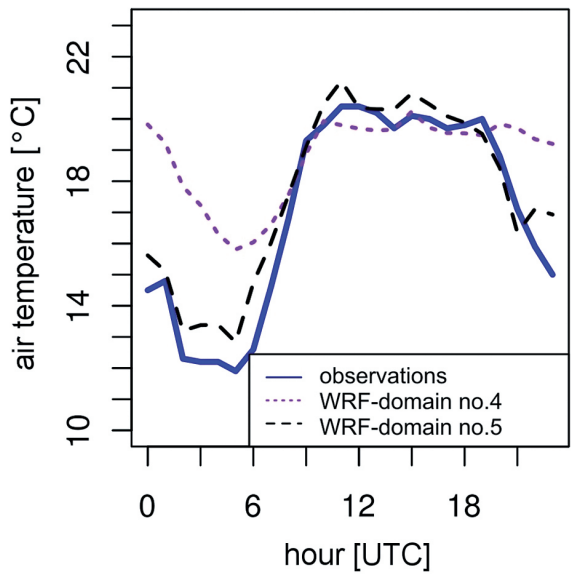

The Keba Sandbar

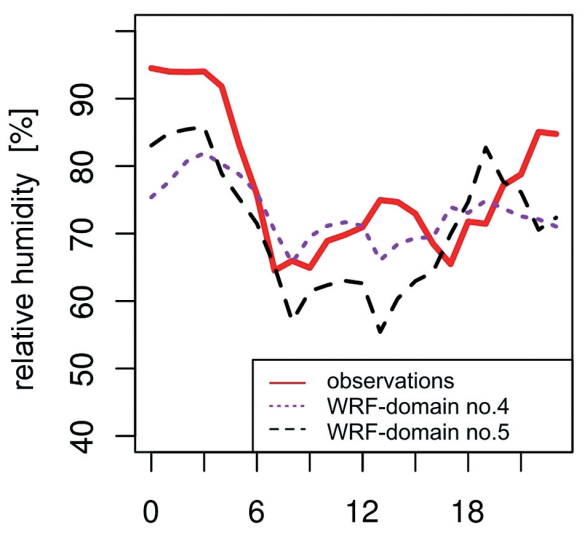

Łeba - Rąbka

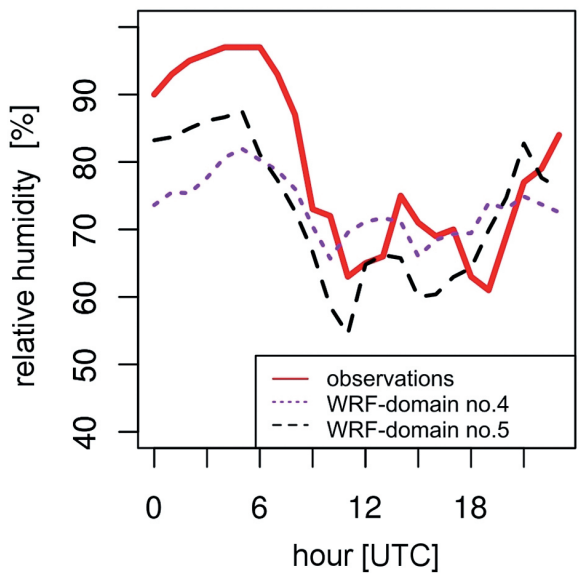

Fig. 5. Daily course of air temperature and relative humidity in the Słowiński National Park on 31.07.2010. Given hours of local time (UTC+2)

\section{Results}

The results derived from the simulation of domains 4 and 5 were used to evaluate the level of agreement in the diurnal cycle of wind speed, wind direction, air temperature and relative humidity, and they were subsequently applied for calculating the selected biometeorological indices. The changes of the vector wind components in both locations are presented on hodographs (Fig. 4a, 4b), while data charts containing the forecast and observed changes of air temperature and relative humidity are shown in Fig. 5.

A detailed analysis indicates a significant influence of the sea breeze on the diurnal course of the meteorological phenomena which in turn affects the thermal sensation. Breeze occurrence may be easily seen by wind direction change, a significant increase of air humidity and de- crease of air temperature in around noon hours, when the wind rapidly changes its direction from offshore to onshore. Most of the typical patterns of breeze circulation are recognized by the model, yet there are some noticeable temporal shifts, especially as regards air humidity, which may be connected with the model coastline representation. The values of wind speeds are also overestimated in almost all cases, which may be due to the problems with terrain data concerning surface roughness (Czernecki 2012).

Both biometeorological indices calculated on the basis of the Łeba-Rąbka station reflect to low variability of sensitive thermal conditions during a chosen day (Fig. 5). The range of the ET-index always belongs to the cold and cool classes, while the $\mathrm{H}$-index oscillates between the cool, slightly cool and neutral classes. More variable results were obtained for the Łeba Sandbar. Both indices 

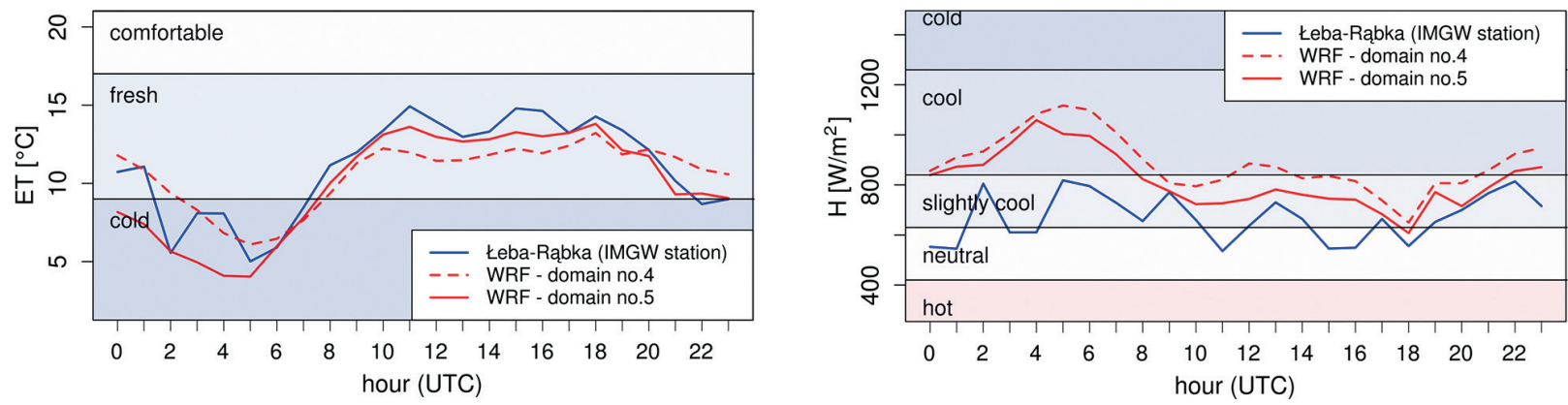

Fig. 6. Daily course of the Effective Temperature (ET) and the Cooling Power of Air (H) in Łeba-Rąbka on 31.07.2010. Given hours of local time (UTC+2)
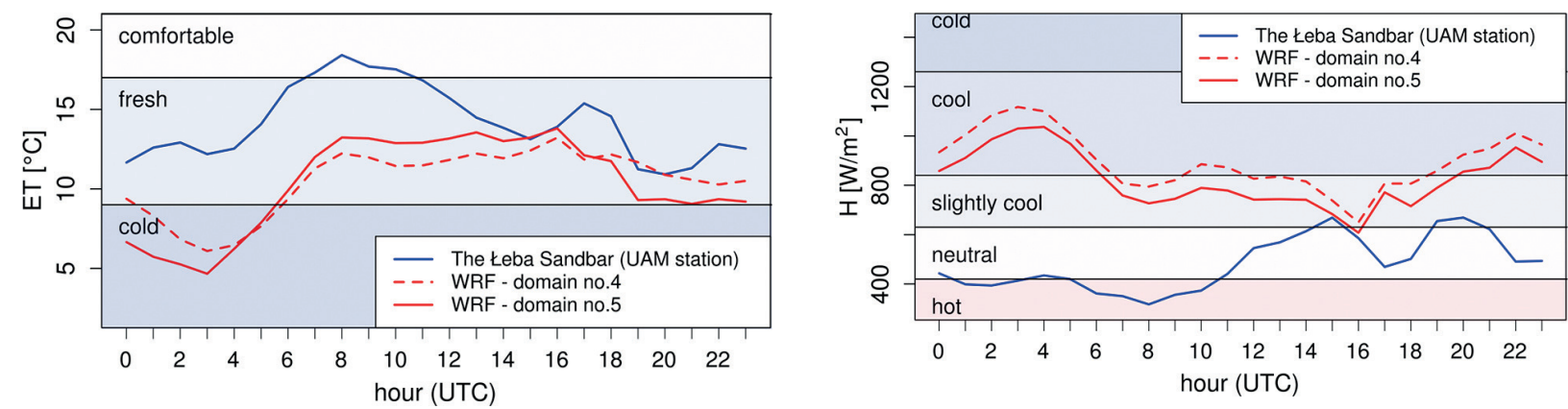

Fig. 7. Daily course of the Effective Temperature (ET) and the Cooling Power of Air (H) at the Łeba Sandbar on 31.07.2010. Given hours of local time (UTC+2)

occur in three classes: ET - cold, cool and fresh, $\mathrm{H}$ - hot, neutral and slightly cool. Due to lower values of the maximum air temperature and higher values of the relative humidity in afternoon hours (in comparison with values that could be expected on days with synoptic-scale driven circulation), there are clearly flattened courses of the ET and $\mathrm{H}$ indices (Fig. 6). The change of the wind direction observed around 10 UTC (Fig. 4b) brings cool and more humid air masses, and due to lower values of surface roughness over the sea it may influence higher wind speed in some distance from coastline. As a result, both indices point out to significantly colder perceived thermal conditions than those usually observed.

An attempt at forecasting the biothermal consequences of breeze circulation gives satisfactory results especially in the case of the Łeba-Rabka station (Fig. 6). The values of ET predicted in domain 5 , between 5 am and $11 \mathrm{pm}$ are the closest to the actually observed values. Only slightly worse are the results for domain 4 , but nevertheless almost all values of the perceived thermal conditions have been classified correctly according to the Michajlow's scale. Larger differences were recognized for the $\mathrm{H}$-index, with some incidents of a 1-class error, and during night hours, also of a 2-class error according to the Petrovič and Kacvinsky's scale.

The Łeba Sandbar may be a more difficult as far as obtaining a reliable forecast outside the sandbar. Model results used for calculating biothermal indices are not fitted well there (Fig. 7). For both indices, the daily course is correlated well, but the model tends to overestimate the H-index and underestimate the ET values. The discrepancy between the model and the observation data is smaller for the ET index with 1-class difference mainly during the morning hours, while the second part of the day is classified in the same range, mainly due to a relatively large range of this class (from $9.0^{\circ} \mathrm{C}$ to $17.0^{\circ} \mathrm{C}$ ). A higher sensitivity of the H-index to wind speed results in larger discrepancies between the observed and modeled biothermal conditions in the Łeba Sandbar, which can vary by as many as 2-3 classes between the night and morning hours.

\section{Conclusions}

The analyzed case study shows a satisfactory level of agreement of the daily breeze circulation 
observed at the selected points of the Słowiński National Park with the forecast dataset obtained from numerical simulations run by the Weather Research and Forecasting (WRF) model. As expected, the model results are closer to the observations for the domains with the smallest horizontal resolution. It means that prediction of local breeze circulation requires not only high-quality boundary conditions, but also high-resolution terrain data. Only slightly worse surface data representation in domain 4 causes poorer results for the part of the day when radiation balance plays an important role in the surface cooling effect. This same effect simulated inside domain 5 is slightly better recognized, however, in the case of the Łeba Sandbar, differences between the observations and simulations are still clearly seen. Confirmation of thesis with misrepresenting thermal fluxes during night hours may be fact of significantly increasing correlation between observed and simulated values of meteorological phenomena just after sunrise (Fig. 5).

However, high quality terrain data did not significantly improve the quality of the wind speed forecast. As presented on hodographs (Fig. 4), even if the wind direction is predicted on a satisfactory level, the wind speed at the Łeba Sandbar is overestimated during the whole day, and in Łeba-Rąbka there are only a few comparable results. Anyway, it must be noticed that in the case of automated measurements in the Łeba Sandbar the results may also be due to the location of the anemometer at a lower height $(3.75 \mathrm{~m})$ and specific location of station, affected by the wind shadow of forest and dunes zone.

Overestimation of the wind speed has further consequences in lower values of the Effective Temperature (ET) and higher values of the Cooling Power of Air $(\mathrm{H})$ in comparison with those calculated from observations (Figs. 6 and 7). H-index values at the Łeba Sandbar may at some hours vary by 2-3 classes according to the Petrovič and Kacvinsky's scale, while the biggest differences were found at night hours. A better quality forecast of the biothermal conditions was obtained in Łeba-Rąbka, where typically the forecasted $\mathrm{H}$-index is lower for 1 class. A satisfactory level of agreement for the effective temperature (ET), especially for the Łeba-Rąbka station (Fig. 6), may also be a result of a relatively wide range (Table 3) of the cool class.

In the analyzed case study, the change of the wind direction from onshore to offshore was observed earlier (around 9:15 am) at the Łeba Sandbar than in Łeba-Rąbka (around 10:30 am). The change of air mass advection results in a temporary decrease of air temperature and an increase of relative humidity values, which is confirmed in both locations. The observed development of breeze circulation influences the lower than usual diurnal amplitude of the biometeorological indices (in comparison with the typical days at the Polish Baltic Coast in the summer season). As a result, the hottest classes according to the Michajlow's, Petrovič and Kacvinsky's scales are not observed.

The case study of forecasting breeze circulation by the Weather Research and Forecasting (WRF) model presented in this paper, with a special focus placed on the biometeorological conditions, may give promising results. The adopted model settings (Table 1 and 2) seem to be adequate for the summer season in the area of interest, which in result let to represent daily course of most of meteorological phenomena typical for breeze circulation. A poorer quality of the forecast as regards the Łeba Sandbar should not be surprising taking into account the topoclimate properties of the chosen station, which cannot be directly solved by the numerical mesoscale model.

Overestimation of the wind speed in the area of interest, which contributes to a lower thermal comfort, seems to be a systematic error, typical for the WRF model (Peña 2011, Czernecki 2013). However, such an assumption in this particular case requires further long-term study, which is necessary before implementing this kind of a forecasting tool for a wide range of end-user needs. Moreover, in places characterized by spatial variation in topoclimate types, as undoubtly is observed in Słowiński National Park (Kolendowicz, Bednorz 2010), application of the Model Output Statistics (MOS) seems to be more adequate to ensure a better quality of site-specific forecasting. 


\section{References}

Bednorz E., Kolendowicz L., 2010. Daily course of the soil temperature in summer in chosen ecosystems of Słowiński National Park, northern Poland. Quaestiones Geographicae 29(1): 5-12.

Błażejczyk K., 1980. Bioklimat Łeby (Bioclimate of Łeba). Problemy Uzdrowiskowe 7(153): 69-97.

Borzyszkowski J., Mordawski J., Treder J., 1999. Historia, geografia, język i piśmiennictwo Kaszubów - jazek i pismienizna Kaszebów. Wydawnictwo Marek Różak, Gdańsk.

Chen F., Dudhia J., 2001. Coupling an Advanced Land Surface-Hydrology Model with the Penn State-NCAR MM5 Modeling System. Part I: Model Implementation and Sensitivity. Monthly Weather Review 129: 569-585.

Chen F., Sun W.Y., 2002. A one-dimensional time dependent cloud model. Journal of Meteorological Society of Japan 80: 99-118.

Czernecki B., 2012. Wyznaczanie szorstkości aerodynamicznej modeli meteorologicznych $\mathrm{w}$ skali lokalnej. In: K. Fortuniak et al. (ed.), Przestrzeń w badaniach geograficznych. Wydawnictwo Uniwersytetu Łódzkiego: 112-119.

Czernecki B., 2013 [accepted]. Creating wind field time-series over the Southern Baltic area using a dynamical downscaling approach. Meteorologische Zeitschrift.

Duś E., 1993. Zagrożenia dla zdrowia w świadomości mieszkańców Górnośląskiego Okręgu Przemysłowego. In: M. Kowalski (ed.), Materiały Konferencji z Geografii Medycznej "Zdrowie a środowisko", UMCS, Lublin: 157-166.

JRC-EEA, 2005. CORINE land cover updating for the year 2000: image 2000 and CLC2000. In: V. Lima (ed.), Products and Methods. Report EUR 21757 EN. JRC-Ispra.

Kain J.S., 2004. The Kain-Fritsch Convective Parameterization: An Update. Journal of Applied Meteorology 43: 170181.

Kolendowicz L., Bednorz E., 2010. Topoclimatic differentiation of the area of the Słowiński National Park, Northern Poland. Quaestiones Geographicae. 29(1): 49-56.

Kondracki J., 2002. Geografia regionalna Polski. PWN, Warszawa.

Kozłowska-Szczęsna T., Błażejczyk K., Krawczyk B., 1997. Bioklimatologia człowieka. Metody i ich zastosowanie w badaniach bioklimatu Polski. Monografie IGiPZ PAN. 1.
Lin Y.-L., Farley R.D., Orville H.D., 1983. Bulk parameterization of the snow field in a cloud model. Journal of Applied Meteorology 22: 1065-1092.

Matzarakis A., 2006. Weather and climate related information for tourism. Tour Hosp. Plan Dev 3: 99-115.

Michalczewski J., 1967. Synoptyczne studium bryz morskich polskiego wybrzeża Bałtyku. PSHM, Warszawa.

Mlawer E.J., Taubman S.J., Brown P.D., Iacono M.J., Clough S.A., 1997. Radiative transfer for inhomogeneous atmosphere: RRTM, a validated correlated-k model for the long-wave. Journal of Geophysical Research 102(D14): 16663-16682.

Papanastasiou D., Melas D., Bartzanas T., Kittas C., 2010. Temperature, comfort and pollution levels during heat waves and the role of sea breeze. International Journal of Biometeorology 54: 307-317.

Pena A., Hahmann A., Hasager C., Bingol F., Karagali I., Badger J., Badger M., Clausen N., 2011. South Baltic Wind Atlas: South Baltic Offshore Wind Energy Regions Project. Technical report, Danmarks Tekniske Universitet, Risø Nationallaboratoriet for Bæredygtig Energi.

Półrolniczak M., 2011. Sensible temperature at the Łeba Sandbar (Słowiński National Park) on selected days of the 2010 summer season. Quaestiones Geographicae 30(3): 83-99.

Reynolds R.W., Smith T.M., Liu C., Chelton D.B., Casey K.S., Schlax M.G., 2007. Daily High-Resolution-Blended Analyses for Sea Surface Temperature. Journal of Climate 20: 5473-5496.

Simpson J., 1994. Sea breeze and local winds. Cambridge University Press. 248 p.

Skamarock W.C., Klemp J.B., Dudhia J., Gill D.O., Barker D.M., Wang W., Powers J.G., 2005. A description of the Advanced Research WRF Version 2. NCAR Tech Notes-468.

Świątek M., 2004. Wieloletnia i sezonowa zmienność wektora wiatru geostroficznego nad południowym Bałtykiem. In: M. Ciaciura (ed.), Stan środowiska przyrodniczego podstawowym warunkiem zdrowotności społeczeństwa, Wyd. Uniw. Szczec. 239-250.

Tijm A.B.C., Holtslag A.A.M., van Delden A.J., 1999. Observations and modeling of the sea breeze with the return current. Monthly Weather Review 127: 625-640. 